\title{
Peptide Inhibitors for Angiotensin I-Converting Enzyme from Masai Fermented Milk
}

\author{
Yoshikazu ISONO \\ Biwako Research Institute, Otsuka Foods Co., Ltd., 1-11-1, Karasaki, Otsu, Shiga 520-01, Japan
}

Received March 25, 1996

The Masai, a nomad living in East Africa, consume a large quantity of fermented milk as the main staple. Angiotensin I-converting enzyme inhibitory activity of their fermented milk was compared with those of commercial ones. Relatively strong activity was detected in their fermented milk. The inhibitory activity in the milk increased during fermentation with Lactobacillus confusus and Lactococcus lactis subsp. lactis which were isolated from the Masai fermented milk as the dominant strains. Two inhibitory peptides were purified by ethanol fractionation and four HPLC steps. Their amino acid sequence were identified as Ser-Leu-Val-Tyr-Pro-Phe-ProGly-Pro-Ile-His-Asn and Lys-Thr-Thr-Met-Pro-Leu-Trp. Their $\mathrm{IC}_{50}$ values were $38.5 \mu \mathrm{M}$ and $28.7 \mu \mathrm{M}$, respectively.

Keywords: angiotensin I-converting enzyme, Masai, fermented milk, Lactobacillus confusus, Lactococcus lactis subsp. lactis

The Masai, a Nailo-Hamic tribe, live a nomadic life in the area between southern Kenya and northern Tanzania. The main staple of their diet is milk from zebu cattle and their milk is usually fermented. An average Masai drinks 3 to $5 l$ of such milk daily (Biss et al., 1970). A previous report (Mtabaji et al, 1990) indicated that the prevalence of hypertension was low in the Masai. These results suggest that their fermented milk may contain an antihypertensive component.

The angiotensin I-converting enzyme (EC 3.4.15.1) is the key enzyme in the blood pressure regulation system. This enzyme catalyzes the conversion of angiotensin I to the potent vasoconstrictor angiotensin II and the inactivation of the vasodilator bradykinin to raise blood pressure. Some synthetic ACE inhibitors show antihypertensive activities and are currently in use as an oral pharmaceutical. Therefore, ACE inhibitory components in foods have the possibility to suppress hypertension. Since ACE inhibitors derived from gelatin were reported in 1979 (Oshima et al.), various ACE inhibitory peptides have been isolated from enzymatic digests of food proteins such as casein (Maruyama et al., 1985; Maruyama \& Suzuki, 1982), zein (Miyoshi et al., 1991), and fish muscle (Ukeda et al., 1992; Seki et al., 1993). The ACE inhibitors actually contained in some fermented foods have also been reported (Kinoshita et al., 1993; Okamoto et al., 1995). Two ACE inhibitory peptides (Val-Pro-Pro and Ile-Pro-Pro) were isolated from sour milk fermented by Lactobacillus helveticus and Saccharomyces cerevisiae (Nakamura et al., 1995). An antihypertensive effect of kefir was also reported (Kuwabara et al., 1995). However, there are few studies about the ACE inhibitory activities of the other traditional fermented milk.

In this study, therefore, the ACE inhibitory activities of Masai fermented milk samples were investigated.

\section{Materials and Methods}

Materials The Masai fermented milk samples were obtained from rural Masai living in 6 regions (Moshi, Sinya, Ngorongoro, Longido, Makuyuni and Monduli) of Northern Tanzania. Plain yogurt, acidphilus milk, sour milk, kefia and unfermented milk were purchased from the market in Otsu city. ACE from rabbit lung was purchased from Wako Pure Chemical Industries Ltd. (Osaka). Benzoyl-glycyl-L-histidylL-leucine (Bz-Gly-His-Leu) was obtained from Peptide Institute Inc. (Osaka).

Assay of ACE inhibitory activity The fluorometric assay for ACE inhibitory activity was done by the method of Cheung \& Cushman (1973) with some modification. ACE and Bz-Gly-His-Leu were dissolved in $100 \mathrm{mM} \mathrm{HEPES}$ buffer, $\mathrm{pH} 8.3$, containing $300 \mathrm{mM} \mathrm{NaCl}$. ACE sol. (100 $\mu 1$, $0.25 \mathrm{mU}$ ) was preincubated with $100 \mu \mathrm{l}$ of inhibitor sol. for 5 $\min$ at $37^{\circ} \mathrm{C}$. The enzyme reaction was initiated by adding 300 $\mu 1$ of $5 \mathrm{~mm}$ Bz-Gly-His-Leu, and the mixture was incubated for $30 \mathrm{~min}$ at $37^{\circ} \mathrm{C}$. The reaction was stopped by the addition of $2 \mathrm{ml} 0.1 \mathrm{M} \mathrm{NaOH}$ then $0.1 \mathrm{ml}$ of $0.2 \% o$-phthaldialdehyde in methanol was added followed after $15 \mathrm{~min}$ by $0.4 \mathrm{ml}$ of $1.5 \mathrm{M}$ phosphoric acid. The fluorescence of the $o$ phthaldialdehyde complex was measured by excitation at 360 $\mathrm{nm}$ and emission at $480 \mathrm{~nm}$. One unit of ACE inhibitory activity was defined as the potency showing 50\% ACE inhibition under these conditions. For the determination of ACE inhibitory activity of the fermented milk, the samples were centrifuged at $10,000 \times g$ for $10 \mathrm{~min}$ after adjusting the $\mathrm{pH}$ to 4.0 with $0.1 \mathrm{M} \mathrm{HCl}$, and the supernatant was used.

Preparation of the Masai fermented milk Lactococcus lactis subsp. lactis MOS-11 and Lactobacillus confusus NGB-82 were used as starter cultures for the preparation of the Masai fermented milk. These strains were isolated as major microorganisms from the Masai fermented milk (Isono et al., 1994). These strains were inoculated $\left(5 \times 10^{6} / \mathrm{g}\right.$ each $)$ 
into the $10 \%$ commercial skim milk, and the cultures were incubated at $30^{\circ} \mathrm{C}$ for $60 \mathrm{~h}$.

Purification of ACE inhibitory peptide from the Masai fermented milk The fermented milk was centrifuged at $3,000 \times g$ for $10 \mathrm{~min}$. To the supernatant, 4 volumes of ethanol was added, then the precipitate formed was removed by centrifugation $(10,000 \times g$ for $10 \mathrm{~min})$. The final supernatant was concentrated to approx. $1 / 25$ volume using a rotary evaporator. The ACE inhibitory peptides were purified from this concentrate by four HPLC steps. The concentrated solution $(0.5 \mathrm{ml})$ was put on an octadecyl silica (ODS) column (Cosmosil $5 \mathrm{C} 18,8 \mathrm{~mm}$ ID $\times 250 \mathrm{~mm}$ L, Nacalai Tesque, Kyoto) and eluted in the linear gradient mode with acetonitrile ( 0 to $50 \% / 30 \mathrm{~min}$ ) containing $0.1 \%$ trifluoroacetic acid (TFA) at a flow rate of $2 \mathrm{ml} / \mathrm{min}$. Individual fractions were dried using rotary evaporator, and were dissolved with $0.25 \mathrm{ml}$ of water (step 1). The fraction with the highest ACE inhibitory activity was rechromatographed on the same column which was developed at a flow rate of $2 \mathrm{ml} / \mathrm{min}$ with a linear gradient of acetonitrile ( 25 to $50 \% / 30 \mathrm{~min}$ ) containing $0.1 \%$ TFA (step 2). The two active fractions from the ODS column were purified on a gel filtration column (Asahipack GS-320 HQ, 8 mm ID $\times 300$ mm L, Showa Denko Co., Ltd., Tokyo). Elution was done with $50 \mathrm{~mm}$ ammonium acetate (pH 6.9) containing 20\% acetonitrile (step 3). For desalting, each active peak was applied on the ODS column under the same conditions at the second step (step 4).

Amino acid sequence analysis The amino acid sequence of the purified peptides were analyzed by a protein sequencer (PSQ-1, Shimadzu, Kyoto).

\section{Results and Discussion}

The ACE inhibitory activities of the Masai and commercial fermented milk samples were measured. All the tested fermented milk samples showed ACE inhibitory activities and their activities were stronger than unfermented milk

Table 1. ACE inhibitory activities of fermented milk.

\begin{tabular}{clc}
\hline Sample No. & Region of origin/Type & $\begin{array}{c}\text { ACE inhibitory act. } \\
(\mathrm{U} / \mathrm{ml})\end{array}$ \\
\hline Masai fermented milk & Moshi & 68 \\
1 & Sinya & 66 \\
2 & Longido & 63 \\
3 & Longido & 68 \\
4 & Longido & 42 \\
5 & Ngorongoro & 49 \\
6 & Ngorongoro & 45 \\
7 & Ngorongoro & 59 \\
8 & Makuyuni & 49 \\
9 & Monduli & 63 \\
10 & Yogurt & 22 \\
11 & Yogurt & 20 \\
12 & Yogurt & 32 \\
13 & Yogurt & 25 \\
14 & Acidophilus milk & 24 \\
15 & Sour milk (conc.) & 46 \\
16 & Kefir & 29 \\
17 & Milk & 3 \\
18 & &
\end{tabular}

(Table 1). Among them, the Masai fermented milks showed relatively strong ACE inhibitory activities (42-68 U/ml). Although sour milk showed potent activity, this is usually diluted 5-6 times for drinking. Commercial plain yogurt, acidophilus milk, and kefia showed moderate ACE inhibitory activities (20-32 U/ml). Usually, Streptococcus thermophillus and Lb. delbrueckii subsp. bulgaricus are used as the starter cultures for yogurt, and sour milk is fermented by $L b$. helveticus and Saccharomyces cerevisiae. On the other hand, $L b$. confusus and Lc. lactis subsp. lactis were isolated from the Masai fermented milk as the dominant strains. The difference in the ability of ACE inhibition may be due to the different microorganisms used for the fermentation.

The Masai fermented milk was prepared using Lc. lactis subsp. lactis and $L b$. confusus. The maximum population of lactic acid bacteria was reached at $12 \mathrm{~h}$, and the $\mathrm{pH}$ was reduced to 4.3 at $18 \mathrm{~h}$. In contrast, the ACE inhibitory activity began to increase in late log phase $(8 \mathrm{~h})$, and reached $50 \mathrm{U} /$ $\mathrm{ml}$ at $40 \mathrm{~h}$. ACE inhibitors were purified from the whey of the Masai fermented milk. After ethanol fractionation, the active fraction was applied on the ODS column. Figure 1A shows the elution pattern and relative ACE inhibitory activities of each fraction. ACE inhibitory activities were found in six fractions. Fraction 7, which had relatively strong activity, was rechromatographed (Fig. 1B). ACE inhibitory activities were spread over ten fractions. Two peptides (peptide I and peptide II) were purified on the gel filtration column from fractions 10 and 11, respectively. Nakamura et al. (1995) reported that most of the ACE inhibitory activity of sour milk was attributed to only two peptides, Val-Pro-Pro and Ile-Pro-Pro. On the contrary, inhibitory activities of the Masai fermented milks were spread over many fractions on the HPLC using the ODS column. From the HPLC results, the ACE inhibitory activities which were attributed to peptide I and peptide II, were evaluated as $7.5 \%$ and $7.0 \%$ of the total activities, respectively. These results indicated that many kinds of inhibitory peptides were contained in the Masai fermented milk. By sequence analysis, peptide I and peptide II were identified as Ser-Leu-Val-Tyr-Pro-Phe-Pro-Gly-Pro-Ile-HisAsn and Lys-Thr-Thr-Met-Pro-Leu-Trp, and these amino acid sequences are found in the primary structure of bovine $\beta$-casein (57-68) and $\alpha_{\mathrm{S} 1}$-casein (193-199), respectively. Their $\mathrm{IC}_{50}$ values and retention times during ODS column chromatography were identical to those of synthetic peptides (Table 2).

In recent years, the $\mathrm{ACE}$ inhibitory abilities of various food-derived peptides (Ariyoshi, 1993) and fermented foods (Kinoshita et al., 1993; Okamoto et al, 1995) have been reported. Some of them showed an antihypertensive effect in spontaneous hypertension rats by oral administration (Yamamoto et al., 1994; Suetsuna \& Osajima, 1989). The Masai fermented milk showed relatively strong ACE inhibitory activity, and their activities were attributed to various inhibitory components. The Masai people drinks 3 to $5 l$ of such milk daily. Mtabaji et al (1990) investigated the relationship between diet, blood pressure, and hypertension in the urban and the rural population containing pastoral Masai in Tanzania. They reported that the blood pressure of the Masai people was not high and the prevalence of 
A
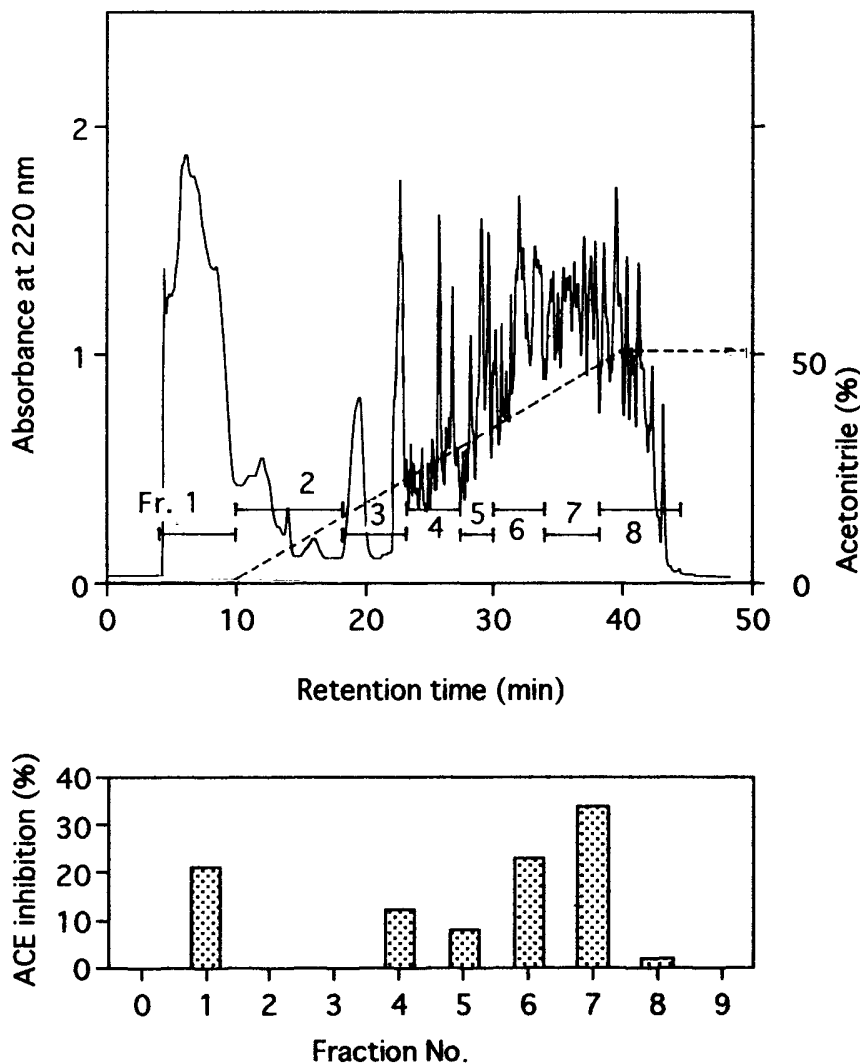

B
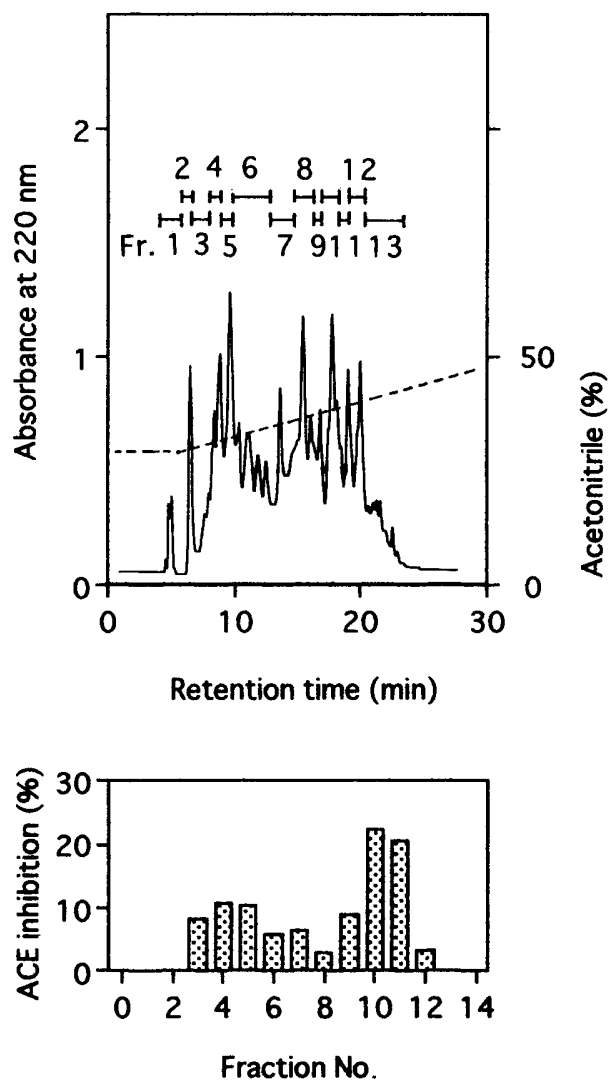

Fig. 1. Purification of ACE inhibitory peptides on ODS column (Cosmosil 5C18). The experimental details are described in Materials and Methods. (A), Chromatogram of the active fraction obtained after treating whey with ethanol. (B), Rechromatogram of fraction 7 on ODS column. Dotted line is the percentage of acetonitrile.

Table 2. Amino acid sequence and inhibitory activity of ACE inhibitory peptides.

\begin{tabular}{|c|c|c|c|c|c|}
\hline \multirow{2}{*}{ Peptides } & \multirow{2}{*}{ Amino acid sequence } & \multicolumn{2}{|c|}{$\mathrm{IC}_{50}(\mu \mathrm{M})^{a)}$} & \multicolumn{2}{|c|}{ Retention time $(\min )^{b)}$} \\
\hline & & Natural & Synthesis & Natural & Synthesis \\
\hline $\mathrm{I}$ & Ser-Leu-Val-Tyr-Pro-Phe-Pro-Gly-Pro-Ile-His-Asn & 38.5 & 34.2 & 17.4 & 17.4 \\
\hline II & Lys-Thr-Thr-Met-Pro-Leu-Trp & 28.7 & 29.1 & 18.8 & 18.8 \\
\hline
\end{tabular}

a) $\mathrm{IC}_{50}$ : concentration of $\mathrm{ACE}$ inhibitor required to inhibit $50 \%$ of the ACE activity.

b) Each peptide was applied on the ODS column under the same conditions at the second purification step (Materials and Methods).

hypertension was the lowest in the Masai. These results must be related to their dietary habits such as low salt intake and high protein intake. Additionally, their fermented milk may contribute to the decrease in the incidence of hypertension in the Masai. However, further investigation including careful physiological tests will be necessary for elucidating the relationship between their fermented milk and blood pressure.

\section{References}

Ariyoshi, Y. (1993). Angiotensin-converting enzyme inhibitors derived from food proteins. Trends Food Sci. Technol., 4, 139-144.

Biss, K., Taylor, C.B., Lewis, L.A., Mikkelson, B., Hussey, L.K. and Jey-Ho, K. (1970). The Masai protection against atherosclerosis. Pathol. Microbiol, 35, 198-204.

Cheung, H.S. and Cushman, D.W. (1973). Inhibition of homogeneous angiotensin-converting enzyme of rabbit lung by synthetic venom peptides of Bothrops jararaca. Biochim. Biophys. Acta, 293, 451-
463

Isono, Y., Shingu, I. and Shimizu, S. (1994). Identification and characteristics of lactic acid bacteria isolated from Masai fermented milk in northern Tanzania. Biosci. Biotech. Biochem., 58, 660-664.

Kinoshita, E., Yamakoshi, J. and Kikuchi, M. (1993). Purification and characterization of angiotensin I-converting enzyme inhibitors from sour milk. Biosci. Biotech. Biochem., 57, 1107-1110.

Kuwabara, Y., Nagai, S., Yoshimitsu, N., Nakagawa, I., Watanabe, Y. and Tamai, Y. (1995). Antihypertensive effect of the milk fermented by culturing with various lactic acid bacteria and a yeast. J. Ferment. Bioeng., 80, 294-295.

Maruyama, S. and Suzuki, H. (1982). A peptide inhibitor of angiotensin I-converting enzyme in the tryptic hydrolysate of casein. Agric. Biol. Chem., 46, 1393-1394.

Maruyama, S., Nakagomi, K., Tomizuka, N. and Suzuki, H. (1985). Angiotensin I-converting enzyme inhibitor derived from an enzymatic hydrolysate of casein, II. Isolation and bradykininpotentiating activity on the uterus and ileum rats. Agric. Biol. Chem., 49, 1405-1409.

Miyoshi, S., Ishikawa, H., Kaneko, T., Fukui, F., Tanaka, H. and 
Maruyama, S. (1991). Structures and activity of angiotensinconverting enzyme inhibitors in an $\alpha$-zein hydrolysate. Agric. Biol. Chem., 55, 1313-1318.

Mtabaji, J.P., Nara, Y., Moriguchi, Y. and Yamori, Y. (1990). Diet and hypertension in Tanzania. J. Cardiovasc. Pharmacol, 16, S3S5.

Nakamura, Y., Yamamoto, N., Sakai, K., Okubo, A., Yamazaki, S. and Takano, T. (1995). Purification and characterization of angiotensin I-converting enzyme inhibitors from sour milk. J. Dairy Sci. 78, 777-783.

Okamoto, A., Hanagata, H., Kawamura, Y. and Yanagida, F. (1995). Anti-hypertensive substance in fermented soybean natto. Plant Food Hum. Nutr., 47, 39-47.

Oshima, G., Shimabukuro, H. and Nagasawa, K. (1979). Peptide inhibitors of angiotensin I-converting enzyme in digests of gelatin by bacterial collagenase. Biochim. Biophys. Acta, 566, 128-137.
Seki, E., Osajima, K., Matsui, T. and Osajima, Y. (1993). Separation and purification of angiotensin I-converting enzyme inhibitory peptides from heated sardine meat by treatment with alkaline protease. Nippon Syokuhin Kogyo Gakkaishi, 40, 783-791 (in Japanese).

Suetsuna, K. and Osajima, K. (1989). Blood pressure reduction and vasodilatory effect in vivo of peptides originating from sardine muscle. Nippon Eiyo Shokuryo Gakkaishi, 42, 47-54 (in Japanese).

Ukeda, H., Matsuda, H., Osajima, K., Matsufuji, H., Matsui, T. and Osajima, Y. (1992). Peptide from peptic hydrolysate of heated sardine meat that inhibit angiotensin I-converting. Nippon Nogeikagaku Kaishi, 66, 25-29 (in Japanese)

Yamamoto, N., Akino, A. and Takano, T. (1994). Antihypertensive effect of the peptides derived from casein by an extracellular proteinase from L. helveticus CP790. J. Dairy Sci., 77, 917-922. 